UDC: 351:332.142.6

Bliznuk Andrii Stanislavovich, Candidate of science in Public Administration, doctoral student of the Interregional Academy of Personnel Management, 01042, Kyiv, Str. Frometivska, 2, tel.: +38 (095) 45217 71, e-mail:abliznyuk1986@gmail.com

ORCID: 0000-0001-8768-5177

Близнюк Андрій Станіславович, кандидат наук з державного управління, докторант кафедри публічного адміністрування, Міжрегіональна Академія управління персоналом, 01042, Київ, вул. Фрометівська, 2, тел.: +38 (095) 452 17 71, e-mail: abliznyuk1986@gmail.com

ORCID: 0000-0001-8768-5177

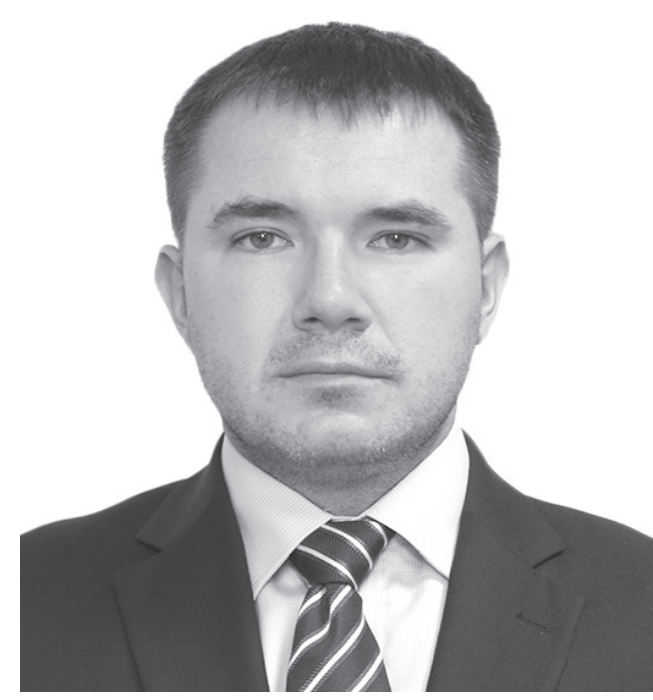

Близнюк Андрей Станиславович,

кандидат наук по государственному управлению, докторант кафедры публичного администрирования, Межрегиональная Академия управления персоналом, 01042, Киев, ул. Фрометовская, 2, тел.: +38 (095) 45217 71, е-таil: abliznyиk1986@gmail.com

ORCID: 0000-0001-8768-5177

DOI: $10.32689 / 2414-0562-2018-15-5-41-51$

\title{
FEATURES OF INSTITUTIONAL SUPPORT OF MECHANISMS OF STATE REGULATION OF RECREATION SPHERE DEVELOPMENT
}

Abstract. The theoretical foundations in the research of institutional support of mechanisms of state regulation of recreational sphere development are systematized and specified.

Attention is drawn to the fact that the institutional support of the recreation sector is shaped by state and non-governmental organizational structures created at different levels of the mechanism and implementing their decisions through the methods of public administration in the recreational sphere within their powers. There are close subordination, coordination and coordination relationships between these organizational structures. The analysis of the functional purpose of the main institutional actors in the recreational sphere is carried out.

The problematic issues of the current state of institutional provision of mechanisms of state regulation of the recreational sphere development in Ukraine are determined. It is noted that the complexity of its regulation lies in the fact that in Ukraine there is not a clear, unified system of state regulation of the recreational sphere, and therefore certain aspects of it in our state are now under the control of many state bodies (ministries, services, agencies). 
It was emphasized that in the system of state management of recreational sphere there is no body that is responsible for carrying out exclusively functions of management of recreational territories; in fact, all state authorities have management functions in relation to reactionary territories and recreational resources, along with functions of management of other resources, objects, territories . The administrative activity of the authorities is aimed at solving the problems of organization, protection of recreational territories and the use of recreational resources to the same extent as for the fulfillment of other tasks in various spheres of society's activity.

The directions of optimization of the institutional mechanism of state regulation of the recreational sphere development are outlined. It is noted that the organizational and economic mechanism should be based on the formation of regional institutions that would allow to concentrate and coordinate the efforts of all subjects of recreational activity in order to achieve the optimal level of recreational potential at the regional level.

Keywords: recreation, recreational activity, institutional mechanism, organizational mechanism, state regulation, mechanisms of state regulation.

\section{ОСОБЛИВОСТІ ІНСТИТУЦЙНОГО ЗАБЕЗПЕЧЕННЯ МЕХАНІЗМІВ ДЕРЖАВНОГО РЕГУЛЮВАННЯ РОЗВИТКУ РЕКРЕАЦІЙНОЇ СФЕРИ}

Анотація. Систематизовано та уточнено теоретичні основи дослідження інституційного забезпечення механізмів державного регулювання розвитку рекреаційної сфери.

Слід звернути увагу на те, що інституційну підтримку сектора рекреації формують державні та неурядові організаційні структури, створені на різних рівнях механізму, та реалізують свої рішення за допомогою методів державного управління в рекреаційній сфері в межах своїх повноважень. Існують тісні підпорядковані, координаційні зв’язки між цими організаційними структурами. Здійснено аналіз функціонального призначення основних інституційних акторів у рекреаційній сфері.

Визначено проблемні питання сучасного стану інституційного забезпечення механізмів державного регулювання розвитку рекреаційної сфери в Україні. Визначено, що складність їі регулювання полягає в тому, що в Украіні відсутня чітка, уніфікована система державного регулювання рекреаційної сфери, тому певні їі аспекти в нашій державі нині перебувають під контролем багатьох державних органів (міністерства, служби, агентства).

Підкреслено, що в системі державного управління рекреаційною сферою немає органу, що відповідає за проведення виключно функцій управління рекреаційними територіями; фактично всі органи державної влади мають функції управління відповідно до реакційних територій та рекреаційних ресурсів, поряд з функціями управління іншими ресурсами, об’єктами, територіями. Адміністративна діяльність органів влади спрямована на вирішення проблем організації, охорони рекреаційних територій та використан- 
ня рекреаційних ресурсів тою мірою, що й для виконання інших завдань у різних сферах діяльності суспільства.

Викладено напрями оптимізації інституційного механізму державного регулювання розвитку рекреаційної сфери. Зазначено, що організаційно-економічний механізм повинен базуватися на формуванні регіональних інституцій, що дасть можливість концентрувати та координувати зусилля всіх суб’єктів рекреаційної діяльності з метою досягнення оптимального рівня рекреаційного потенціалу на регіональному рівні.

Ключові слова: рекреація, рекреаційна діяльність, інституційний механізм, організаційний механізм, державне регулювання, механізми державного регулювання.

\section{ОСОБЕННОСТИ ИНСТИТУЦИОНАЛЬНОГО ОБЕСПЕЧЕНИЯ МЕХАНИЗМОВ ГОСУДАРСТВЕННОГО РЕГУЛИРОВАНИЯ РАЗВИТИЯ РЕКРЕАЦИОННОЙ СФЕРЫ}

Аннотация. Систематизированы и уточнены теоретические основы исследования институционального обеспечения механизмов государственного регулирования развития рекреационной сферы.

Следует обратить внимание на то, что институциональную поддержку сектора рекреации формируют государственные и неправительственные организационные структуры, созданные на разных уровнях механизма, и реализуют свои решения с помощью методов государственного управления в рекреационной сфере в пределах своих полномочий. Существуют тесные подчиненные, координационные связи между этими организационными структурами. Проведен анализ функционального назначения основных институциональных актеров в рекреационной сфере.

Определены проблемные вопросы современного состояния институционального обеспечения механизмов государственного регулирования развития рекреационной сферы в Украине. Отмечено, что сложность ее регулирования заключается в том, что в Украине отсутствует четкая, унифицированная система государственного регулирования рекреационной сферы, поэтому некоторые ее аспекты в нашем государстве сейчас находятся под контролем многих государственных органов (министерства, службы, агентства).

Было подчеркнуто, что в системе государственного управления рекреационной сферой нет органа, который отвечает за проведение исключительно функций управления рекреационными территориями; практически все органы государственной власти имеют функции управления по отношению к реакционным территориям и рекреационным ресурсам, наряду с функциями управления другими ресурсами, объектами, территориями. Административная деятельность органов власти направлена на решение проблем организации, охраны рекреационных территорий и использования рекреационных ресурсов в той же степени, что и для выполнения других задач в различных сферах деятельности общества. 
Изложены направления оптимизации институционного механизма государственного регулирования развития рекреационной сферы. Отмечено, что организационно-экономический механизм должен базироваться на формировании региональных институтов, которые позволят концентрировать и координировать усилия всех субъектов рекреационной деятельности с целью достижения оптимального уровня рекреационного потенциала на региональном уровне.

Ключевые слова: рекреация, рекреационная деятельность, институциональный механизм, организационный механизм, государственное регулирование, механизмы государственного регулирования.

Problem statement. A characteristic feature of the progressiveness of structural changes in the economy is the development of the service sector and the growth of its share in the gross domestic product, which is due to the general trend of improving the living standards of the population and its desire to constantly expand opportunities to meet their diverse needs. An important role in this process is played by the recreational sphere, the functioning of which is aimed primarily at preserving and restoring health, as well as providing a wide range of additional services related to the full and active recreation of citizens. Consequently, the recreational sphere has a complex structure of its manifestation in the public life of Ukraine, and therefore for its effective functioning and development state coordination and regulation is required. Providing conditions for the creation of an effective and coordinated system of state regulation of the recreational sphere of Ukraine, in our opinion, is an important factor in its sustainable socio-economic development. At the same time, it is the institutional support of the state regulation of the recreational sphere that is characterized by complexity, inconsistency and incompleteness, which hinders its development.

Analysis of recent researches and publications. The study of problems of state regulation of the recreational sector is studied in the works of V. I. Byrkovych, N. G. Bila, M. M. Bilynska, V. N. Vasylenko, N. R. Nyzhnyk, D. V. Karamyshev, S. I. Kushch, V. P. Meged, Ya. F. Radysh, O. I. Chernysh, O. S. Shaptal, A. Donabedian, L. Forrest, C. Kaspar, J. Krippendorf, etc.

However, a significant part of the research on the regulation of the recreational sphere does not take into account the specifics and features of the institutional support of the mechanisms of state regulation of the development of the recreational sphere. In addition, this problem was not considered comprehensively and did not contain such components as scientific substantiation, financial, logistical and regulatory support.

The purpose of the article is to develop theoretical foundations and practical approaches to improving the institutional support of the mechanisms of state regulation of the development of the recreational sphere. 
Presentation of the main material. Defining the system of public administration recreational sphere, it is necessary to take into account their managerial competence in this area. That is, the bodies of state administration of the recreational sphere include those bodies that are endowed with state-power functions in order to fulfill their tasks in the field of protection of recreational areas and the use of recreational resources, and the effectiveness of management depends on the completeness of the competence of the subjects of management in the legislation.

Among the bodies of state administration of the recreational sphere it is worth to highlight the Verkhovna Rada of Ukraine, which plays a special role in the regulation of relations for the protection of recreational areas, as in this area it is endowed with exclusive competence. Namely, to the jurisdiction of the Verkhovna Rada of Ukraine, first of all, is the legislative regulation of relations in the field of protection of recreational areas and the use of recreational resources and the definition of the main directions of state policy in this area [1]. The exclusive powers of the Verkhovna Rada of Ukraine in the field of recreation include: the definition of the main directions of state policy in the recreational sphere; the definition of the legal framework for the regulation of relations in the recreational sphere, their improvement and adaptation to the generally recognized norms of international law; the definition in the law on the state budget of Ukraine of financial support of the recreational industry [2].

Management functions in the field of protection of recreational areas and the use of recreational resources are endowed to the Cabinet of Ministers of Ukraine. Thus, the government implements the environmental policy defined by the Verkhovna Rada of Ukraine, ensures the development of regional environmental programs. Also, the Cabinet of Ministers of Ukraine makes a decision on the organization of territories and objects of nature reserve fund of national importance, that is, the administrative competence of the government in the field of protection of recreational areas and the use of recreational resources extends to recreational areas that are part of the territories and objects of the natural reserve fund of national importance (for example, in the territories of national parks a zone of regulated recreation and the area of stationary recreation, biosphere reserves-zone of anthropogenic landscapes and the like are allocated).

In addition, the general management of health and medical institutions is carried out by the Cabinet of Ministers of Ukraine, by specially authorized Central Executive authority on the activities of resorts, as well as regional and Kyiv city state administration, other executive authorities and local self-government.

The main powers of the Cabinet of Ministers of Ukraine in the field of resorts include: establishment of rules and regulations for the use of natural medicinal resources; organization of state accounting of natural medicinal resources, therapeutic areas and resorts; approval of the regime of districts and zones of sanitary protection of resorts of national importance; approval of the order of monitoring of natural areas of resorts and the order of creation and maintenance of the state cadastre of 
natural areas of resorts of Ukraine and the state cadastre of natural medicinal resources of Ukraine [3].

Consequently, the Cabinet of Ministers of Ukraine in accordance with the Constitution and laws of Ukraine: carries out public administration and ensures the implementation of state policy in the field of recreation; develops and approves programs for the development of the recreational sphere in Ukraine and finances their implementation in accordance with the budget legislation; adopts legal acts regulating relations in the field of recreational activities; ensures the rational use of recreational resources and taking measures for their preservation; promotes the development of the recreational industry and the creation of an effective recreational infrastructure; organizes and ensures the implementation of the state investment policy in the field of recreational activities; prepares and submits to the Verkhovna Rada of Ukraine as part of the draft law on the State budget of Ukraine for the relevant year proposals on the amount of budget funds for financial support of projects and programs for the development of recreation; informs the Verkhovna Rada of Ukraine on the implementation of the program of recreation in Ukraine; creates a state system of scientific support in the field of recreational activities, etc. [4].

Implementing powers in the recreational sector, particularly in relation to protection of recreational areas and use of recreational resources, the Cabinet of Ministers issues resolutions and orders that are binding and have normative, organizational and competenceconstituent character. Government acts are aimed at regulating relations in which the direct objects are both recreational areas that are part of other territories and objects to be protected, as well as recreational areas and recreational resources.

The Ministry of ecology and natural resources of Ukraine (Ministry of natural resources) is the main body in the system of central executive authorities, which ensures the formation and implementation of the state policy in relation to the recreational sphere, carries out its management functions in accordance with the Law of Ukraine "On environmental protection" and the Regulations on the Ministry of ecology and natural resources of Ukraine. The management competence of the Ministry of natural resources as to the natural resources is general, since the management in the field of protection of recreational areas and the use of recreational resources is carried out along with the management of the use and protection of other natural resources, natural objects and territories. And the main tasks of the Ministry of natural resources do not include the tasks regarding the protection of recreational areas and the use of recreational resources, they include only the general tasks - to ensure the rational use, reproduction and protection of natural resources, conservation, reproduction and sustainable use of biological and landscape diversity, the formation, conservation and use of the ecological network, organization, protection and use of the natural reserve fund. Most of the powers of the Ministry of natural resources in the field of protection of recreational areas and the use of recreational resources relate to recreational areas, which are part of the 
individual territories and objects of the natural reserve fund.

Within the framework of the administrative structure of the Ministry of natural resources of Ukraine, there are central executive bodies that also regulate the recreational and tourism sector, namely the State Environmental Inspectorate, the State Service of Geology and subsoil of Ukraine, the State Agency for water resources of Ukraine, the State Agency for environmental investments of Ukraine, the State Agency for the management of the exclusion zone, the State Agency for environmental investments.

Special attention in the system of state bodies of management of recreational areas should be paid to the State Environmental Inspectorate (State Ecological Inspectorate of Ukraine), whose competence includes the functions of control in relation to the rational use, reproduction and protection of natural resources, in particular, natural recreational resources, compliance with the regime of territories and objects of the natural reserve fund, in particular, recreational areas included in their composition.

Through the Minister of agrarian policy and food, the Cabinet of Ministers of Ukraine directs and coordinates the activities of the State Forest Resources Agency of Ukraine (State Forestry Agency). State state Agency is the Central Executive authority that implements the state policy in the field of forestry and hunting. Regarding the powers in the field of recreation, it is the State Agency that decides on the classification of forests to the appropriate category. After all, forest areas that perform recreational, sanitary and health-improving functions are used for tourism, sports, spa treatment and recreation of the population, belong to the category of recreational forests.

At the same time, it should be noted that not all issues related to the state regulation of recreational nature management are within the competence of the Ministry of ecology and natural resources, some of them are attributed to the powers of the central executive authorities, whose activities are coordinated and directed by the Ministry of agrarian policy and food of Ukraine.

However, it should be noted that the system of state recreational policy of Ukraine is not limited to the abovementioned institutions. The complexity of its regulation lies in the fact that Ukraine has not created a clear, unified system of state regulation of the recreational sphere and therefore certain aspects of it in our country are managed by many state bodies (ministries, services, agencies, etc.).

Among them are the following ministries: the Ministry of Social Policy of Ukraine, the Ministry of Health, the Ministry of Youth and Sports of Ukraine. After all, it is within their powers to ensure the implementation of state policy in the field of health, sanitary and epidemic well-being of the population, social protection, compulsory state social insurance, pensions, social services, collective and contractual regulation of social and economic interests of employees and employers, the development of social dialogue; the implementation of the general legal, social, economic and organizational foundations of physical culture and sports in Ukraine and the participation of state bodies, officials, as well as enterprises, 
institutions and organizations, regardless of ownership, in strengthening the health of citizens, achieving a high level of work capacity is carried out and longevity by means of physical culture and sports is ensured and monitored.

The Ministry of culture of Ukraine is an important state institution regarding the regulation of certain aspects of the recreational and tourism sector. In accordance with the established procedure, it makes proposals on the formation of state policy in the resort industry, ensures its implementation, carries out management in this area, as well as inter-sectoral coordination. The main objectives of the Ministry are to participate in the formation and implementation of the state policy in the resort industry; development and implementation of national programs for the development of resorts and tourism and recreation, tourism services market, protection and safety of tourists; definition of prospects and directions of development of the recreational sphere, the development of material and technical base of recreation; inter-sectoral coordination and functional regulation on recreation; organization and development of the system of scientific, information and advertising support of

The subjects of state administration of the recreational sphere are also represented by the central executive authorities represented by the Ministry of Infrastructure of Ukraine and the State Agency of tourism and resorts of Ukraine, as well as by specialized departments under the regional state administrations.

At the local level, local state administrations and local self-government bodies are vested with managerial powers in the organization, protection of recreational areas and use of recreational resources.

Due to such differentiation of spheres of influence among the administrative vertical, it is necessary to add that these state structures are not able to control the whole range of relations arising in the process of recreational activities in Ukraine. Also, a certain share of powers in the management of the recreational sphere is performed by the following bodies: tax inspections in cities, managers and heads of subjects of recreational activities, intermediary firms, subjects of advertising and communication, and the like. That is, in a sense, subjects and persons of different forms of ownership are involved in the field of recreational services.

It should be noted that the activity of state regulation structures of the recreational sphere locally also has similar problems in the regions. This, above all, depends on the lack of understanding by the local authorities of the importance of the recreational sector for the development of the local economy and the need for regulation at the local level and to some extent due to the lack of highly qualified specialists on recreation in local authorities and among workers in the region.

In the context of consideration of this issue, it should be emphasized that in the system of public administration of the recreational sphere there is no body whose competence is the implementation of exclusively functions of management of recreational areas, in fact, all state bodies are endowed with management functions in relation to reactionary areas and recreational resources, along with the functions of 
management of other resources, objects, territories. Management activities of the bodies are aimed at solving the problems of organizing the protection of recreational areas and the use of recreational resources to the same extent as the implementation of other tasks in various spheres of society.

In addition, in Ukraine we observe constant reforms to change the central body of the general state level, which is responsible for the management of the recreational industry. We believe that this is extremely negative, because frequent reorganization and redistribution of powers between existing and newly created state structures neutralize the possibility of systematic functioning of the mechanism of state management of the recreational industry at all management levels.

Due to the fact that Ukraine proclaims recreation as one of the priority directions of economic and cultural development and creates conditions for recreational activities, there is an urgent need for structural changes in the system of public authorities engaged in state regulation of the recreational sphere at all levels. Moreover, the improvement of public authorities engaged in the regulation of the recreational sphere at the local, regional and central levels should be in line with the improvement of other branches of the Ukrainian government.

A clear distribution of rights and responsibilities of different levels of management is a prerequisite for the effectiveness of the management system of the recreational industry. Consequently, the link of the government's management of recreational activities should: develop the concept of the de- velopment of the recreation sector, the mechanism for its implementation and support of process implementation; design and submission to the Parliament legislative initiatives; preparation and submission of proposals to the Cabinet of Ministers for the coordination of ministries and departments on the development of the recreational industry, its infrastructure, material and technical base, recreational enterprises, subordination of all forms of ownership; organization of new recreational areas; creation and provision of the national information and advertising system of the industry; organization of advertising activities with targeted investment projects in the country and abroad.

The functions of the regional administration (departments of recreation) should include: the functions of monitoring the quality of service of holidaymakers, licensing recreators, certification of accommodation facilities (hotels, campsites, recreation), encouraging the development of innovative tourist and recreational product, a new service, search for potential investors.

At the same time, studying the system of public administration in the recreational sphere, it is necessary to take into account the level of territorial distribution of their powers. For sustainable use of recreational resources and protection of recreational areas, first of all, it is necessary to ensure the optimal balance of national and local interests in the creation of a system of public administration in this area, because the local authorities are most aware of the problems of the area and the needs of the population, which makes it possible to take into account such specifics 
in the implementation of management functions.

Effective institutional support should operate on the principles of transparency, efficiency, economy and provide for active cooperation with other structures, including non-state ones, which are interested in the development of the recreational industry. The main task of such provision should be the creation of favorable conditions for the development of the recreational sphere. That is, we can identify such basic requirements for the construction of an effective institutional support of the mechanism of state management of the recreational sphere: the elimination of duplication and differentiation of functions in the activity; specialization and unification of management functions by levels and organizational and economic units; reduction and reduction of costs for the maintenance of the administrative apparatus; efficiency, stability, flexibility and reliability of the institutional structure.

At the local level, the imperfection of the organizational and functional structure of the recreational sphere management is most clearly manifested. Small inspection units with low material and technical support can fully meet the needs and requirements of society for proper monitoring of the environment and improving its quality. Based on this, the organizational and economic mechanism should be based on the formation of regional institutions that would allow to concentrate and coordinate the efforts of all subjects of recreational activities to achieve the optimal level of use of the creative potential at the regional level. At the same time, it is important to coordinate the activi- ties of services that operate in the field of recreation, to create a single rational system of information support, a system of control, analysis and expertise.

The solution of the problems connected with the institutional principles of state regulation of the recreational sphere will allow to make structural changes in the system of the state power of Ukraine for the purpose of creation in the state of integral system of state regulation of the recreational sphere.

Conclusions. Thus, the institutional support of the recreation industry is formed by state and non-state organizational structures that are created at different levels of the mechanism and implement their decisions through the methods of public administration in the recreational sphere within their powers. Among these organizational structures close subordinate, reordering and coordination relationships exist.

\section{REFERENCES}

1. Gaman P. (2015), "Features of functioning of the mechanism of state regulation of tourism development at the regional level", Derzhava ta rehiony, vol. № 2, p. 39-44.

2. Lazor O. (2011), "Bodies of state administration in the field of ecology and natural resources", Visnyk UADU, vol. № 4, p. 195-202.

3. Rosetovoy O. (2017), "Theoretical Basis of State Regulation of the Development of the Recreation-Health-Tourist Complex", Derzhava ta rehiony, vol. № 4, p. 183-188.

4. Cherchik L. (2012), "Directions of improvement of public administration in the field of recreational nature use", Nauk.-inform. visn. Akad. nauk vysch. osvity Ukrainy, vol. № 2 (79), p. 105112. 


\section{СПИСОК ВИКОРИСТАНИХ} ДЖЕРЕЛ

1. Гаман П. Особливості функціонування механізму державного регулювання розвитку туризму на регіональному рівні / П. Гаман // Держава та регіони. - 2015. - № 2. С. 39-44.

2. Лазор О. Органи державного управління в галузі екології та природних ресурсів / О. Лазор // Вісник УАДУ. - К. : УАДУ, 2011. - № 4. C. 195-202.
3. Розметова О. Теоретичні засади державного регулювання розвитку рекреаційно-оздоровчо-туристичного комплексу / О. Розметова // Держава та регіони. - 2017. - № 4. C. 183-188.

4. Черчик Л. Напрями удосконалення державного управління у сфері рекреаційного природокористування / Л. Черчик // Наук.-інформ. вісн. Акад. наук вищ. освіти України. -2012 . - № 2 (79). - С. 105112. 